\title{
Yaşlı İstismarı ve İhmali
}

\author{
Pınar YEŞİL ${ }^{1}$, Sultan TAŞCI², Gürsel ÖZTUNÇ
}

\section{ÖZ}

Yaşlı istismarı, yaşıııın sağlı ve iyilik halini tehdit eden veya zarar veren herhangi bir davranışa maruz kalmasıdır. Yaşlı ihmali ise yaşlının sosyal, fiziksel ve duygusal ihtiyaçlarının karşılanmasında bilinçli veya bilinçsiz yetersizlik oluşması olarak adlandırılır. Yaşlılık dönemindeki fiziksel ve sosyo-kültürel değişimler ile ekonomik koşullardaki kötüleşme, yaşlının evde veya kurumdaki bakımının yeterince desteklenememesine, istismar ve ihmale neden olan durumlardır. Yaşlı istismarı ve ihmalinin önlenmesinde istismar ve ihmal belirtilerini ve risk gruplarını bilmek önemlidir. Sağlık profesyonelleri yaşlı istismar ve ihmalini ortaya çıkarma, yönetme ve önlem almada önemli konumdadırlar. Bu doğrultuda, bir profesyonel olarak hemşirelere önemli sorumluluklar düşmektedir. Hemşireler, istismar ve ihmali önlemeye odaklı hemşirelik bakım planı geliştirmeli, uygulamalı ve değerlendirmelidir.

Anahtar Kelimeler: Yaşl1lık; istismar; ihmal.

\begin{abstract}
Elder abuse is an act that endangers health and wellness of elderly person. Neglect is called as intentional or unintentional failing to meet the physical, social or emotional needs of the elder person. Physical and socio-cultural structure changes and worsening of the economic conditions in old age, are the conditions that cause poorly supported caring of the elderly at home or institution, elder abuse and neglect. It is important to know the signs of neglect and abuse, and risky groups in avoiding abuse and neglect of the elderly. Health professionals are a central position to reveal, manage and prevent elder abuse and neglect. In this context, nurses as a professional have important responsibilities. Nurses should make a plan, implement and evaluate nursing process that will be focused on to prevent abuse and neglect.
\end{abstract}

Elder Abuse and Neglect

Keywords: Old age; abuse; neglect.

\section{GİRIS}

"Yaşlılık" sözlük anlamı olarak yaşlı olma, artmış yaşın etkilerini gösterme hali olarak tanımlanmaktadır (1). Dünya Sağlık Örgütü (DSÖ) ise, yaşlılığı çevresel etmenlere uyum sağlama yeteneğinin azalması ya da büyük oranda kaybolması olarak tarif etmektedir (2). Yaşlılık önüne geçilmesi mümkün olmayan biyolojik, kronolojik, sosyal yönleri ve sorunları olan bir süreç olduğundan yaşl11ık sürecinde meydana gelen bu fiziksel, psikolojik ve psikososyal değişimler de birbiriyle ilişkili olmaktadır $(1,3)$.

Tüm dünyada doğum oranlarında düşme, yaşam standartlarının iyileşmesi ve buna bağlı olarak insan ömrünün uzamasıyla birlikte yaşlı nüfusun toplam nüfus içindeki payı hızla artmaktadır (3). 2010 yılında yayınlanan 'Birleşmiş Milletler, Dünya Nüfus Beklentileri Raporu'na göre; ortalama ömrün, 2010 y1lında dünyada 69.31 yıl olduğu belirtilmekte, 2050 yılında ise 75.5 yıla yükseleceği tahmin edilmektedir (4). Türkiye ise, yaşlanma sürecinin hızla gerçekleşeceği ülkelerden birisidir. 2010 yılında Türkiye'de ortalama ömrün 74.60 yıl olduğu belirtilmekte, 2050 yllında ise 78,5 yıla yükseleceği tahmin edilmektedir (4).

Teknolojik gelişmelerin yaşam koşullarına olumlu katkıları, sağlı hizmetlerindeki nitelikli gelişmeler ile yaşlı nüfusun genel nüfusa oranı artmış, bu durum toplumlarda yeni sorunların ortaya çıkmasına neden olmuştur (3). Yaşlılık, fiziksel ve bilişsel fonksiyonlarda gerileme, sağlığın, üretkenliğin, rol ve statünün, bağımsızlığın, sosyal yaşantıların, desteklerin azalması ve kaybı gibi döneme özgü pek çok sorunun ve kayıpların yaşandığı bir süreçtir (5).

\footnotetext{
${ }^{1}$ Çukurova Üniversitesi Sağlık Bilimleri Fakültesi, Hemşirelik Bölümü

${ }^{2}$ Erciyes Üniversitesi Sağlık Bilimleri Fakültesi, Hemşirelik Anabilim Dalı

Correspondence: Pınar YEŞiL, e-posta: pnar.yesil@gmail.com
}

Geliş Tarihi / Received: 09.04.2015 Kabul Tarihi / Accepted: 24.11.2015 
Hızlı sanayileşme ve kentleşme sonucu, ekonomik ve sosyal yapıda hızlı değişmeler, tarımsal düzenden kent ve sanayi düzenine doğru hareket, geniş aileleri çekirdek aileler halinde bölünmeye zorlamaktadır. Bu durum, geniş aile kurumunda çözülme ve çekirdek aileye dönüşmeye, bireyler arasında geçimsizliklere, bağımsızlık isteğine, oturulan evi dar ve yetersiz bulma gibi sorunlara neden olmaktadır (6). Yaşlılık dönemindeki fiziksel ve sosyokültürel değişimler ile ekonomik koşullardaki kötüleşme, yaşlının evde veya kurumdaki bakımının yeterince desteklenememesine, istismar ve ihmale neden olan durumlardir $(6,7)$.

\section{YAŞLI İSTISMARI VE İHMAL KAVRAMI}

Uluslararası Yaşlı İstismarının Önlenmesi Kuruluşu ve DSÖ Toronto Deklerasyonu "Güven beklentisi olan herhangi bir ilişkide yaşlıya zarar veren veya strese sokan tek ya da tekrarlayan uygunsuz davranışlarda bulunulmasını yaşlı istismarı olarak tanımlamaktadır" (810).

İhmal ise yaşlının sosyal, fiziksel, duygusal ihtiyaçlarını karşılamada bilinçli veya bilinçsiz yetersizliktir $(7,11)$. İstismarda şiddeti uygulayan kişi aktif bir tutum içerisindeyken, ihmalde ihmal eden kişi daha çok pasif bir tutum içerisindedir (12).

\section{DÜNYA'DA VE TÜRKIYYE'DE YAŞLI İSTISMARI VE İHMALI}

Yaşlı istismarı kavramı, ilk olarak 1975'te İngiltere'de bilimsel literatürde, bakıma muhtaç bir yaşlının kendisine bakan bir aile üyesi tarafindan fiziksel istismara uğramasıyla ortaya çıkmıştır (11). Amerika Birleşik Devletleri (ABD)'de yaşlı istismarı, 1978 yılında aile içi şiddet konusu kapsamında ulusal düzeyde tartışılmaya başlanmış ve 1979 yılında özel yaşlı istismarı yasası oluşturulmuştur. ABD'de her yil bir milyondan fazla yaşlının istismar mağduru olduğu ve yaklaşık \%25'nin ise fiziksel olarak istismar edildiği belirtilmektedir (13).

Hollanda'dan bildirilen ve bir yıllık istimar oranlarının araştırıldığ 1 bir çalışmada, yaşlıların \%5.6'sının istismara maruz kaldığı bulunmuştur (14). Yaşlı istismarı ve ihmali vakalarının artmasının en önemli olası nedeni ise, yaşlıların yaşam sürelerinin uzamasına bağlı olarak yaşlı sayısının artması olarak belirtilmektedir (9).

Oh ve ark.'nın (15) Kore'de yaşlı istismarını belirlemeye yönelik yaptıkları çalışmalarında, 15.230 katılımcıdan 1319'unun fiziksel istismara, 2550'sinin duygusal istismara, 1814'ünün ekonomik istismara, 2292'sinin sözel saldıraya ve $1625^{\prime}$ inin ise ihmale maruz kaldığ belirlenmiştir.

Sauza ve ark.'nın (16) Brezilya'nın Fortaleza şehrindeki yaşlılara karşı uygulanan şiddete ilişkin kayıtları analiz ettikleri çalışmalarında, 424 kayıttan, 284'ünde (\%67) yaşlıların terk edildiği, \%38'inin umursamazlık, \%19'unun sözlü saldırı, \%16'sının ise fiziksel saldırıya maruz kaldıkları belirlenmiştir.

Dong ve ark.'nın (17) Chicago Sağlık ve Yaşlanma Projesi kapsamında yaşlının kendi kendini ihmalinin, yaşlı istismarı ile ilişkisini araştırdıkları çalışmalarında ise;
10,333 katılımcıdan 1,460'nın kendini ihmal ettiği ve 180 'inin ise istismara maruz kaldığı belirlenmiştir.

Dong ve Simon'un (18) Chicago Sağlık ve Yaşlanma Projesi kapsamında yaşlı kişilerde hastaneye yatış için bir risk faktörü olarak yaşlı istismarını değerlendirdikleri diğer çalışmalarında ise; psikolojik istismarın, mali sömürünün, bakıcı ihmalinin ve iki veya daha fazla yaşlı istismar türünün, hastaneye yatış oranlarındaki artış ile ilişkili olduğu bulunmuştur.

Günümüzde ülkemizde de yaşlıya karşı uygulanan ihmal, istismar ve şiddet, polislerin ve araştırmacıların dikkatini çekecek boyutlara ulaşmaya başlamıştır (12). Yaşlı nüfus, gerek kurumlar kapsamında gerekse kendi aileleri içerisinde şiddet/istismara maruz kalmaktadır. Yaşlı anne babanın, emekli maaşlarının ellerinden alınması ya da sözlü tacize maruz kalmaları, yaşlı hakları ihlaline en güzel örneklerdir. Aile içerisinde de yaşlıların, diğer aile üyelerinden fiziksel şiddetin yanı sıra ekonomik istismar/tacize uğradıkları belirtilmektedir (19). Ülkemizde yaşlı bakımının genellikle aile içinde ve sıklıkla yaşlının çocukları tarafından yapıldığı, çocukların yetersiz kaldığı durumlarda ise kurum bakımına gereksinim duyulduğu bilinmektedir. Bu süreçte ortaya çıkan sorunların yaşlıyı olduğu kadar yaşlıya bakan kişileride etkilediği söylenebilir.

Artan'ın (20) aile içi fiziksel yaşlı istismarını belirlemeye yönelik yaptığı çalışmasında, 113 yaşlının (\%25.66) yaklaşık dörtte birinin fiziksel istismara maruz kaldığ 1 bulunmuştur.

Keskinoğlu ve ark.'nın (21) İzmir ili İnönü Sağlık Ocağ1 Bölgesi'nde 65 yaş ve üzeri 204 bireyi içeren fiziksel, finansal örselenme ve ihmal konulu çalışmalarında, yaşl1ların $\% 1.5^{\prime} \mathrm{in}$ fiziksel, \%2.5'inin finansal örselenme ile karşılaştığ,$\% 3.5$ inde kesin ihmal bulgusu, \%28.9'unda ise olası ihmal bulgusu saptanmıştır.

İlhan'ın (22) aile içi yaşlı istismarının saptanmasına yönelik yaptığı çalışmasında, 65 yaş ve üzerindeki 275 kişinin $\% 18.2$ 'sinde aile içi yaşlı istismarı olduğu, yaşlı istismarının \%40.5' ini duygusal istismar, \%29.7'sini ihmal, $\% 20.3$ 'ünü ekonomik istismar ve $\% 9.5$ 'ini fiziksel istismarın oluşturduğu belirlenmiştir.

Ergönen ve ark.'nın (23) jinekoloji polikliniğine başvuran kadınlarda yaşı istismarına ilişkin çalışmalarında, katılımcıların \%22.6'sı kendilerine yakın insanların onları yaralamaya ve zarar vermeye çalıştıkları saptanmıştır.

Günümüzde tüm dünyada yaşlı nüfusun artışı ile birlikte artan yaşlı istismarının yaşlıların yakınları ya da bakımlarını üstlenen kişiler tarafından daha sıklıkla

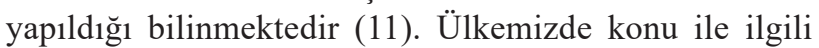
yapılan çalışmaların yetersiz olduğunu söylemek mümkündür.

\section{YAŞLI İSTISMAR VE İHMAL ÇEŞITLERİ}

Yaşlıya kötü muamele, fiziksel, emosyonel/psikolojik, cinsel, ekonomik istismar ve ihmali kapsamaktadır $(24,25)$.

Fiziksel İstismar: Yaşlının güvendiği veya yaşlıya bakan birisi tarafından güç kullanarak vücuda zarar verme, ağrı verme, yetersizliğe yol açma, fiziksel olarak engel olma, zorla besleme ve yatakta tutma gibi eylemlerdir. 
Açıklanamayan yaralar, yanıklar, çürükler ve izleri, tokat vurma, sarsma, dövme ya da kötü niyetle ilaç uygulama, fiziksel istismar kapsamında yer almaktadır $(6,8,26,27)$.

Emosyonel/Psikolojik İstismar: Yaşlının güvendiği konumda olan birisi tarafindan sözel veya sözel olmayan yolla ruhsal açıdan acı veren veya strese sokan davranışlardır. Örnek olarak sözel saldırı, küçümseme, aşağılama, gözdağı verme, tehdit etme, utandırma, sürekli eleştirme, korkutma, lakap takma, zorla çevresinden ayırma vb. yer almaktadir $(6,8,26,31)$.

Cinsel İstismar: Yaşlının isteği dışında herhangi bir türde cinsel ilişkiye girilmesidir. Yürümede ve oturmada güçlük, yırtık, lekeli ve kanlı iç çamaşırı, genital bölgede ağrı ve kaşıntı, isteği olmadan dokunma, tecavüz, zorla soyundurma, açık şekilde cinsellik içeren fotoğraf çekme vb. cinsel istismar kapsamında yer almaktadır $(6,8,26,27,31)$.

Ekonomik İstismar: Yaşlının güvendiği konumda olan birisi tarafindan yasal ve yasal olmayan şekilde parasının veya malının kötüye kullanılması veya çalınmasıdır $(6,8,26,31)$.

İhmal: Bilerek veya bilmeden yaşıı bireyden yiyecek, içecek, ilaç, tıbbi cihaz gibi (protez, gözlük, işitme cihazı) ihtiyaçlarını esirgemek, bakım vermedeki sorumluluklarını yerine getirmede isteksiz davranarak veya reddederek yaşlıya duygusal, fiziksel acı ve sıkıntı vermektir. Örnek olarak yeme, giyinme, 1sınma, kişisel hijyen gibi gereksinimlerin karşılanmaması, duygusal-sosyal uyarının sağlanmaması, uzun zaman yalnız bırakılması vb. yer almaktadır $(6,8,26,31)$.

Yaşlı İstismar ve İhmali için Risk Faktörleri

Yaşlı istismarı ve ihmalinde hem yaşlı hem de bakım veren açısından bazı risk faktörleri bulunmaktadır $(6,7,9)$.

Yaşlı Bireye Ait Özellikler:

- Bağımlılık ve yetersizlik hali (sağlık sorunları, ekonomik nedenler vb),

- Kalabalık aile ortamı içerisinde yaşaması, statü ve güç kaybına uğraması,

- Dul veya boşanmış olması,

- Yalnız yaşaması ve izole olması,

- Cazip maddi kaynağının olması,

- Mental yetersizliğinin ve özürlülüğün olmas1,

- İleri yaşlarda (70-75 ve üzeri) olmasıdır $(6,7,9)$.

İstismarcıya Ait Özellikler

- Üstlendiği bakım rolünü benimsememesi ve zorunlu yapmasi,

- Bakım verdiği kişiyle zıt olması ve kırgın roller üstlenmesi,

- Kişilik problemleri (düşük benlik saygısı, düşünce ve davranışlarının kontrol edememe),

- Parasal ve tıbbi problem, evlilik çatışması, işsizlik gibi diş stresörler,

- Madde bağımlısı olması,

- Şiddet ve istismarı çözüm olarak algılamasıdır $(6,7,9)$.
Sosyal ve Kültürel Özellikler

- Toplu ve birlikte yaşama,

- Maddi problemler (işsizlik),

- Aile içi şiddet ve uyumsuzluk,

- Sosyal destek eksikliği,

- Yaşam tarzı, özel hayatın olmaması,

- Şiddetin nesiller boyu görülerek öğrenilmesi,

- İstimara karşı toplumun göstereceği tepki (dini, ailesel),

- Aile bireylerinin yaşliya bakmak konusunda kültürel olarak koşullanması,

- Şiddetle ilgili kültürel inanışlar,

- Cinsiyet ayrımcılığıdır $(6,7,9)$.

\section{YAȘLI ISTISMAR VE IHMALININ SAPTANMASINDAKİ ZORLUKLAR}

Yaşlı istismarı özellikle son yıllar içerisinde üzerinde durulan ciddi bir toplumsal sorundur. Her toplumda, her kültürde ve her ekonomik düzeyde görülebilmektedir. İstismar, sadece aile içinde veya genel nüfusta değil, sağlık ve sosyal hizmetlerin verildiği kurumlarda da görülen fiziksel ve psikolojik olarak yaşlıya zarar verme ve ondan faydalanma şeklinde kendini göstermektedir $(7,12,28)$.

Yaşlı istismarı ve ihmalinde en önemli konu, problemin farkında olamamak ya da saptanmasındaki zorluklardır. Sağlık personelinin yaşlı bireyi değerlendirmede göz önüne alması gereken bu zorlukların nedenleri; kişisel ve ailevi nedenler, bilgi ve kaynaklara ulaşmada yetersizlik, sağlik çalışanları ve kurumsal engeller olarak sıralanabilir $(28,29)$.

\section{Kişisel ve Ailevi Engeller}

Ailenin kutsal sayılması, dokunulmazlığının olması ve başkaları tarafından aile yaşantısına müdahale edilmesinin kabul edilemez olmasıdır. Bu sorun özellikle geleneksel toplumlarda daha belirgin olarak gündeme gelmektedir (2830).

-Yaşlı istismarı bireyi kuşatan ev içerisinde gerçekleşir. Yaşlı birey çok az bazen de hiç evin dışına çıkmayabilir. $\mathrm{Bu}$ nedenle yaşlıya uygulanan istismarın, aile üyeleri dışındaki bireylerden saklanması kolaydır. Böyle bir durumda istismar fark edilemeyebilir (28-31).

- Yaşı ı bireyler aileleri ya da akrabaları tarafından yapılan istismarı bildirmede isteksiz olabilirler. Yaşlı birey ailesinde böyle bir problemin olduğunu kabul etmeyebilir, ailesinin davranışlarından utanabilir ya da bu olayı birilerine söylediğinde yakınlarının kendilerine daha kötü davranabileceklerinden ve herhangi bir kuruma gönderileceğinden korkabilir. Yaşlılar şu anda yaşadı̆̆ probleme kendisinin sebep olduğunu düşünür ve kimseye bildirmek istemeyebilir (28-31).

Ayrıca kişisel ve ailevi engeller arasında yaşlı bireyin;

-Bakıcısı tarafindan yargılanacağından, suçlanacağından korkmas1,

-Kimsenin kendisine inanmayacağından korkması, -Sisteme karşı güven eksikliğinin olması,

-Yaşanan durumu kendi suçu olarak görmesi, kimse ile paylaşmak istememesi ya da istismarı

bildirmede isteksiz olması,

-Yaşadığı durumu yeterince ciddi olarak değerlendirmemesi olarak belirtilmektedir $(6,30)$. 
Bilgi ve kaynaklara ulaşmada yetersizlik

-Yaşlının nereden, nasıl yardım alabileceği ile ilgili kaynakların farkında olmaması,

-Yaşlının ekonomik ya da sosyal olarak bağımsız olmamasidır $(6,30)$.

Sağlık çalışanları ve kurumsal engeller

-Hemşire, doktor, sosyal hizmet uzmanı gibi sağlık personelin yaşlı istismarını ortaya çıkarmada hangi soruları soracağını bilmemesi, konu ile ilgili bilgi eksikliğinin olmas1,

-Sağlık personelinin problemi bildirme ve kaydetmede yetersiz ya da isteksiz olması,

-Sağlık çalışanlarının değerlendirme ve eyleme geçmede sorumluluk alma ile ilgili tedirginliğinin olmasıdır $(6,29$ 31).

Yaşlı istismarının saptanması farklı disiplinlerin birlikte yaklaşımını gerektirmektedir. Bu nedenle yaşlı bireylerin istismar ve ihmaline yönelik engellerin ortadan kaldırılmasında ve bu bulguların tanılanmasında sağlık profesyonellerine önemli görevler düşmektedir.

YAŞLI İSTISMARI VE İHMALININN ÖNLENMESINDE MODELLER

Yaşlı istismarının önlenmesinde temel amaç, yaşlı bireyi korumak ve daha ileri istismarı önlemektir. Bu sürece yönelik genel olarak "eș istismarı modeli”,"destekleyici model" ve "yetişkin koruma" olmak üzere üç model benimsenmiştir. Eş-istismarı modelinde, istismara uğrayan bireyin çatışma çözülene kadar istismar edilen ortamdan uzaklaştırılmasıdır. İstismara uğrayan birey önlemleri almak için yetkilidir. Buna rağmen bu model, özellikle istismara uğrayan yaşlı birey için yaşadığı ev kendininse ve taşınma ile ilgili isteksizse uygun olmayabilir. Destekleyici modelde, istismar eden ve istismara uğrayan yaşı birey ile ilişkisi olmayan bir kişi yaşlı bireye yardım etmektedir. İstismara uğrayan yaşlı bireyin hak ve özgürlüklerinin yasalar ve sağlık personelleri aracılığı ile desteklemesi ve yürütülmesini içerir. Yetişkin-koruma modeli, istismarın zorunlu olarak bildirilmesini ve kurum destekli bakımın sürdürülmesini içerir. Ancak henüz yetkili alanlarda etkisi kanıtlanmış değildir. Her model problemin tanımlanması, bilgi sağlanması, yaşlı bireyin karar verme kapasitesi ve seçimler yapmasına yardımı içermesine rağmen, destekleyici model genel olarak en uygun model olarak kabul edilmektedir $(9,32,33)$.

Ülkemizdeki sağlık sisteminin işleyişi içerisinde bu modellerin kullanımı mümkün olmamaktadır. Yaşlı istismarının bildirileceği kurumların oluşturulması ile bu modeller de uygulama alanına geçirilebilir (9).

\section{İSTISMAR EDENLERINN TANIMLANMASI}

İstismar edenlerin tanınması, istismarın erken fark edilmesi açısından önemlidir. İstismar edenlerin büyük çoğunluğu primer bakıcılar olarak tespit edilmektedir. Erişkin çocuklar $(\% 50)$, eşlerden $(\% 20-40)$ daha fazla istismar edenler olarak karşımıza çıkmaktadırlar. Yaşlı kişinin bakımını üstlenen kişi/kişilerin özelliklerinin bilinmesi, istismardan şüphe edilmesi durumunda risk arttırıcı faktör olarak kabul edilmektedir (9).

Yaşlı istismarı ve ihmalinin tanılanabilmesi için American
Medical Association (AMA) tarafindan belirlenmiş yaşlı bireyle her karşılaşmada mutlaka sorulması önerilen bazı sorular bulunmaktadir (31):

- Herhangi bir birey size zarar veriyor mu?

- İzniniz olmadan herhangi bir birey size dokunuyor mu?

- İstemediğiniz bir şeyi yapmak için zorlama yaşıyor musunuz?

- Sizin izniniz olmadan size ait birey alınıyor mu/alındı mi?

- Size açıklama yapılmadan ya da anlamadığınız bir evrak imzalatıldı mı?

- Evde yalnız kalmaktan korkuyor musunuz?

- Kendinizi yalnız/ihmal edilmiş hissediyor musunuz?

- Herhangi bir konuda yardıma gereksinimiz olduğunda bunu alabiliyor musunuz?

Ayrıca istismarcı bakıcıların tanınması için Caregiven abuse screen (CASE) ad1 verilen bir program geliştirilmiştir. Bu yöntemle istismarcı bakıcı ve istismara uğrayan yaşlı diğerlerinden kolayca ayırt edilebilmektedir. $\mathrm{Bu}$ programa göre $2-3 \mathrm{dk}$. içinde bakıcıya 8 soru yöneltilmektedir $(8,32,35)$ :

-Huy ve davranışları nedeniyle aranızda zaman zaman problem çıkıyor mu?

-Karakteriniz dışında bir şeyi yapmaya zorlandığınız oldu mu? veya yaparken kendinizi berbat hissettiğiniz oldu mu? -Onun davranışlarını kontrol etmekte zorlandığınız oluyor mu?

-Onun için yapmak zorunda olduğunuz işleri yapmadığınız oluyor mu?

-Onu önemsemediğiniz oluyor mu?

-Onun isteklerini, ihtiyaçlarını yapmak için isteksiz ve yorgun mu oluyorsunuz?

-Ona sık sık bağırmak istiyor musunuz?

Sorulara "evet" cevabı arttıkça istismar olma olasılığ 1 artmaktadır $(8,32,35)$. Yaşlıyı bakıcıdan korumak için medyan skor 4'tür. Her "evet" cevabının ayrıntılı bir biçimde sorulması gerekmektedir $(8,35)$.

Sağlık personelinin hastadan, ailesinden, arkadaşlarından oldukça fazla bilgi almaya ve bütün verileri dikkatlice yakalamaya çalışması gerekmektedir. Yaşlılar özellikle istismarcı çocukları olduğunda, onları suçlamak yerine genellikle kendilerini suçlamaktadırlar. Örneğin; "Ben kötü bir anneyim", "Bu benim hatam, oğlumun hapishaneye gitmesini istemiyorum", "Ona son bir şans vermek istiyorum" diyebilir. Bu nedenle de hastayla konuşularak bu düşüncesinden vazgeçirmede ve istismarcı davranışları açıklaması için onu cesaretlendirmede sağlık personeline önemli görevler düşmektedir. Ayrıca yaşlılar genellikle demans ya da mental bir hastalıkları olduğu için istismarcı davranışları anlatmak için yeterli olgunlukta olamayabilirler. Bu durumda aile içinden, komşulardan, yaşlı bireyin arkadaşlarından, istismar davranışına yönelik bilgiler alınmaya çalışılmalıdır (8).

İSTISMAR VE İHMAL DURUMUNDA HEMȘİRELİK YAKLAŞIMI

Yaşlı istismar ve ihmalini tanımlama, hemşireler için profesyonel bir sorumluluktur (27). Çünkü hemşireler, yaşlı bireylerle sık karşılaşmalarından dolayı gerçek ve şüpheli 
durumları tespit etmede ve bunlara müdahale etmede en önemli konumdadırlar (6).

Yaşlı bireyleri korumada, onlar için sağlıklı, doğru kararlar almada ve sahip olduğu yasal hakların sürdürülmesinde hemşirelerin yasal sorumlulukları vardır (6). Hemşirelerin kötü davranılan ve ihmal edilen yaşlıyı tanıyabilmesi için yaşlı ve ona bakım verenler hakkında detaylı bir bilgiye sahip olması, yaşlıyı ve bakım vereni çok iyi gözlemesi ve tanıya yardımcı olabilecek belirti ve bulguları çok iyi bilmesi gerekir (28). Hemşire, istismar açısından yaşlı bireyin değerlendirilmesini; görüşme ve öykü alma, fiziksel, psikolojik, cinsel istismar ve yetersiz bakımı değerlendirme gibi altı alanda yapmalıdır (36).

Yaşlı bireyin istismar açısından değerlendirilmesi, öncelikli olarak görüşme ve öykü alma (hem yaşlı hem de bakım vereni/bakıcı) ile başlar. Görüşme yaşlının isteksiz olması veya utanması durumunda bakım vereni/ bakıcıdan ayrı yapılmalıdır. Soru sorma, yaşlının evde güvenlikle ilgili algısını içeren genel sorular ile başlamalıdır. Daha detaylı sorular, daha fazla özelliği açıklaması açısından yaşlı bireyin yaşadığı/deneyimlediği istismar durumu ile ilgili olmalıdır. Hemşire, elde edilmesi gereken bilgilerin türünü ve miktarını azaltacağından çatışmacı bir yaklaşımdan kaçınmalıdır. Böylece, yargılamayan bir yaklaşım daha etkili olacaktır (36).

Fiziksel istismarda yaşlı birey; genel görünüm, hijyen, bakım ve uygun elbise, cilt durumu (dehidratasyon, kesikler, 1sırıklar, delikler, morluklar ve yanıklar vb. gibi)

Tablo 1. Yaşlı İstismarı ve İhmalini Uyarıcı Belirteçler (31)

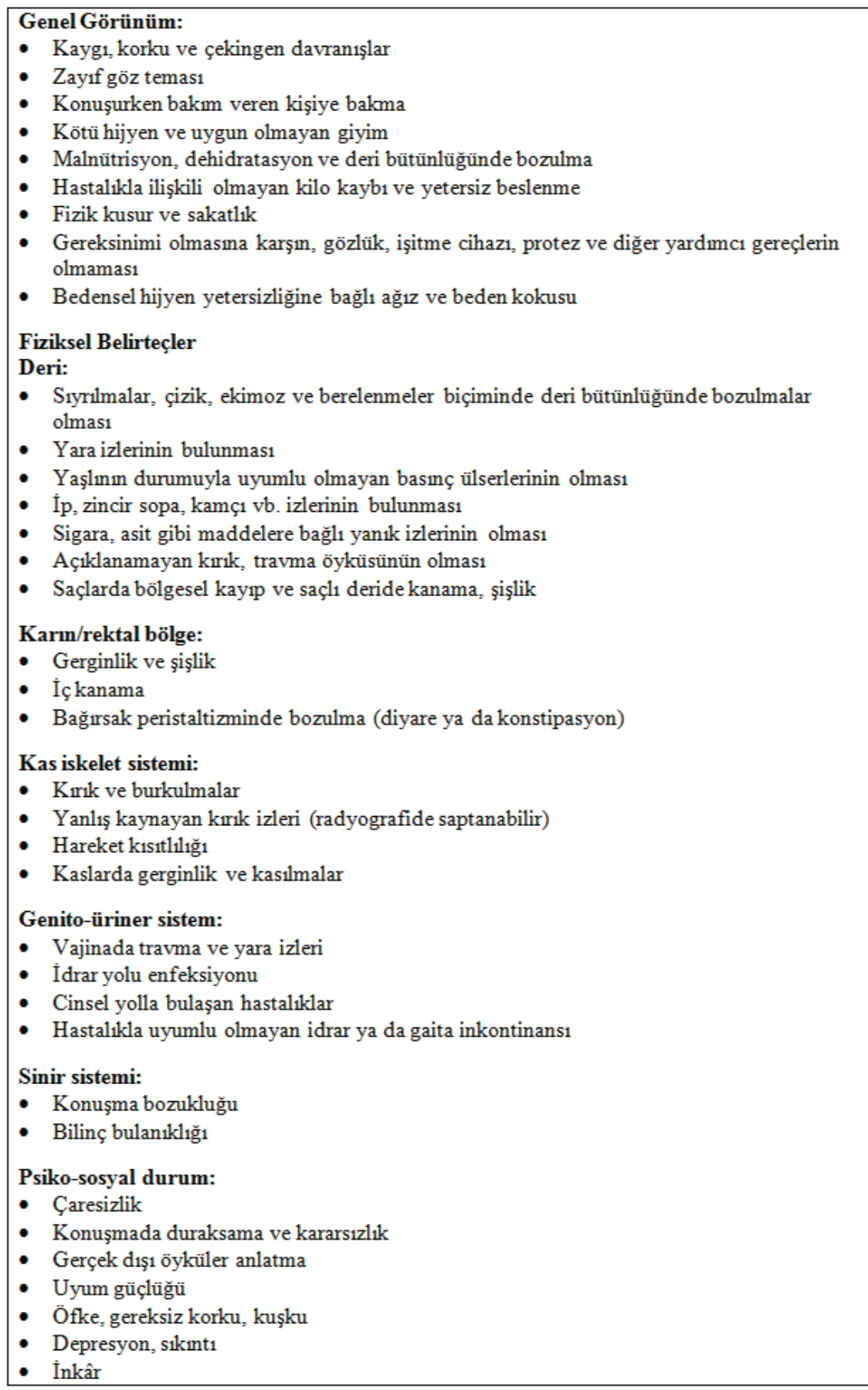


açısından değerlendirilmelidir (36). Yaşlı birey cinsel istismarda, oturmada ve yürümede zorluk, kanlı ve lekeli iç çamaşırı, cinsel organda kaşıntı ve ağrı gibi durumlar açısından değerlendirilmelidir (27). Cinsel istismar şüphesi varsa yaşlı bireyin cinsel yolla bulaşan hastalıklar için laboratuvar ve fiziksel olarak değerlendirilmesi gerekir $(31,36)$. Yaşlı ihmal ve istismarı ile ilgili uyarıcı olabilecek belirteçler Tablo 1'de verilmiştir (31). Hemşireler çalışma ortamı gereği, risk altındaki yaşlılar ile sık olarak karşılaşmaktadırlar. Bu nedenle bu uyarı belirteçlerinin yaşlı bireyle karşılaşılabilecek ev, kurum, hastane vb. tüm alanlarda mutlaka dikkatle değerlendirilmesi ve kayıt etme kurallarına göre kayıt ve bildiriminin yapılması gerekmektedir (31). Ayrıca olayın tıbbi, psikolojik, yasal ve etik yönü olduğu düşünüldüğünde, hemşirenin diğer meslek grupları ile ekip anlayışı içinde çalışması gerekmektedir (9). Ekip içerisindeki hemşire, yaşlının güvenli bir ortamda olmasını sağlama, yaşlıya bakım verenlere yardım ve rehberlik etme, aile üyeleri arasında daha yakın ilişkiler kurmada gerekli olan iletişimi geliştirme ve stresli bakım vericiler için kaynak bulma gibi konularda yardımcı olmalıdır (36).

\section{YAŞLIYA YÖNELIK İSTISMAR VE İHMALIN ÖNLENMESINDE ÖNERİLER}

Yaşlı istismarı ve ihmalini önlemede sağlık profesyonellerinin farkındalı̆̆ 1 , ihmal ve istismar belirtilerini tanıması ve risk gruplarını bilmesi yaşlı bireye yardım etmede son derecede önemlidir (29). Yaşlı istismar ve ihmalini belirlemeye ve önlemeye ilişkin şu öneriler siralanabilir;

- Toplumun ve özellikle yaşlıya bakım veren sağlık personeli, aile üyelerinin yaşlılık ve sorunları, yaşlı istismarı ve ihmali konusunda bilgilendirilmesi ve bu konuda medyanın desteğinin de alınması $(29,31)$,

- Yaşlıya sevgi ve saygı bilincinin kazandırılmasında ailelere ve eğitim kurumlarına önemli sorumluluklar düşmektedir. Bu bağlamda ilköğretim, lise ve üniversiteleri kapsayan aktiviteler planlanması (29),

- Özellikle istismar ve ihmal yönünden risk taşıyan yaşlı bireylere (Alzheimer, demans gibi mental sorunu olan hastalar gibi) bakım verenlerin sorumluluklarını yerine getirmede yaşadıkları bilgi ve beceri eksikliği, korku, anksiyete, stres, davranış sorunları, baş etmede yetersizlik, iletişim kurma ve tedavi gibi konularda topluma yönelik eğitim, danışmanlık ve sosyal destek hizmetlerinin sağlanması (29),

- Yaşlılık konusunda politikaların üretilmesi ve bu politikaların yaşama geçirmesi konusunda ilgili kurumların daha duyarlı davranmasi $(29,31)$,

- Yasal önlemler olarak yaşlıya;

-İlerde yetersizlik yaşayabileceği durumlarda yasal açıdan koruyacak birilerini, örneğin kendisini temsil edecek bir avukat veya yasal güçten destek ve öneriler alması,

-Yasal ve sosyal anlamdaki görüşmelerini periyodik olarak devam ettirmesi,

-Banka hesaplarını veya sosyal güvenlik evraklarını kontrol ederek düzenlemeler yapması (29),

-Yanında güvenebileceği biri olmadan ve incelemeden herhangi bir doküman veya evrak imzalamamas1, evden yalnız ayrılmaması önerilebilir $(7,28)$.

Ülkemizde yaşlı bakımıyla ilgili yürürlükte olan mevzuatın toplumun sosyo-kültürel yapısına uygun olarak güncelleştirilmesi gerekmektedir. Yaşlılık politikalarının geliştirilmesinde temel felsefe üç amacı kapsamalıdır (29):

- Öncelikle yaşlıların parasal güvencesi teminat altına alınmalidir.

- Yaşlıların topluma aktif katılımını sağlayacak olanaklara yer verilmelidir.

- Yaşliların kendilerini geliştirmelerine, sağlıklı yaşlanmalarına ve sağlıklı yaşamlarına olanak sağlayacak hizmetler sunulmalı ve ortamlar yaratılmalıdır.

\section{SONUÇ}

Yaşlı nüfusun toplam nüfusa oranının artmasıyla yaşlı istismarı-ihmali artış göstermekte ve yaşlıları inciten, yaralayan ve yaşama alanlarını daraltan bir sorun olmaya devam etmektedir. İstismar ve ihmalin rapor edilmesi zorunludur. Bu nedenle istismar ve ihmali yaşayan bireyin, tanık olan kişinin, doktor, hemşire ya da sosyal hizmet uzmanının bu durumu bildirmeleri yasal zorunluluk ve sorumlulukları kapsamındadir. Genel olarak toplumda bu problem ile ilgili olarak bilgilendirilmeye ihtiyaç vardır ve bu yüzden uygun hizmetler (eğitim hizmetleri, güvenliği sağlayıcı hizmetler vs.) sağlanmalı ve geliştirilmelidir. Uygun hemşirelik girişimleri ile yaşlı istismarı ve ihmali belirlenebilir, istismar ve ihmal döngüsü kırılabilir.

Birçok ülkede potansiyel risk grupları için acil hizmetler mevcuttur. Ülkemizde de şiddete sıfır tolerans ilkesi ile şiddetin önlenmesinde sağlık, güvenlik ve adalet sektörü ile tüm toplumun yakın işbirliğinin sağlanması çok önemlidir (6).

\section{KAYNAKLAR}

1. Akduman GG, Korkusuz İ, Akduman B. Yaşlı ihmal ve istismar1. Adli Psikiyatri Dergisi. 2006; 3(2): 3-8.

2. Launch of the World report on ageing and health [Internet]. Geneva 2015. [Updated 2015; Cited: 2015 Nov 15]. Available from: www.who.int/ageing/en/

3. Beğer T, Yavuzer H. Yaşlılık ve yaşlılık epidemiyolojisi. Klinik Gelişim. 2012; 3(25): 1-3.

4. Aile ve Sosyal Politikalar Bakanlığı: Türkiye'de Yaşlıların Durumu ve Yaşlanma Ulusal Eylem Programı [İnternet]. Ankara 2013. [Son güncelleme tarihi: Kasım 2013; Erişim tarihi: 25 Eylül 2014] Erişim adresi: www.eyh.gov.tr/upload/Node/8638/files/blob.docx

5. Polat Ü, Kahraman BB. Yaşlı bireylerin sağlıklı yaşam biçimi davranışları ve algılanan sosyal destek arasındaki ilişki. Fırat Tıp Derg. 2013; 18(4): 213-8.

6. Kıssal A, Beşer A.Yaşlı istismar ve ihmalinin değerlendirilmesi. TAF Prev Med Bull. 2009; 8(4): 35764.

7. Sayan A, Durat G. Yaşlı istismarı ve ihmali:önleyici girişimler. Atatürk Üniv. Hemşirelik Yüksekokulu Dergisi. 2004; 7(3): 97-106.

8. Halil GM. Yaşlı suistimali ve yaşlıda iyatrojenik problemler. Arıoğul S, editör. Geriatri ve gerontoloji. Ankara: Medikal\&Nobel; 2006. s.1073-82. 
9. Yıldırım KY. Yaşlı istismarı ve önlenmesi. Ege Üniversitesi Hemşirelik Yüksek Okulu Dergisi. 2005; 21(1): 167-74.

10. Elder abuse [Internet]. World Health Organization. Geneva 2014. [Updated: 20155 June; Cited: 2015 Nov 9]. Available from: www.who.int/mediacentre/ factsheets/fs357/en/, accessed

11. Kurt G, Beyaztaş YF, Erkol Z. Yaşlıların sorunları ve yaşam memnuniyeti. Adli Psikiyatri Dergisi. 2010; 24(2): 32-9.

12. Erkal S. Aile içi şiddet ve yaşlılar. Hacettepe Üniversitesi e-Dergisi [Internet]. 2008 Ağustos [Erişim tarihi: 09 Eylül 2015]: 1-8. Erişim adresi: www.sdergi.hacettepe.edu.tr/makaleler/ yaslivesiddet.pdf

13. Switzer JA, Michienzi AE. Elder abuse: an update on prevalence, identification, and reporting for the orthopaedic surgeon. J Am Acad Orthop Surg. 2012; 20(12): 788-94.

14. Comijs HC, Pot AM, Smit JH, Bouter LM, Jonker C. Elder abuse in the community: prevalence and consequences. J Am Geriatr Soc. 1998; 46(7): 885-8.

15. Oh J, Kim HS, Martins D, Kim H. A study of elder abuse in Korea. Int J Nurs Stud. 2006; 43(2): 203-14.

16. Souza JA, Freitas MC, Queiroz TA. Violence Against the aged:documental analysis. Rev Bras Enferm. 2007; 60(3): 268-72.

17. Dong X, Simon M, Evans D. Elder self-neglect is associated with increased risk for elder abuse in a community-dwelling population: findings from the Chicago Health and Aging Project. Journal of Aging and Health. 2013; 25(1): 80-96.

18. Dong X, Simon MA. Elder abuse as a risk factor for hospitalization in older persons. JAMA Intern Med. 2013; 173(10): 911-7.

19. Dural B, Con G. Türkiye'de sosyal devlet ve yaşlı hakları üzerine bir inceleme. Sosyal Haklar Uluslararası Sempozyumu III; 25-26 Ekim 2011; Kocaeli. 2011. s.483-96.

20. Artan T. Aile İçi Fiziksel Yaşlı İstismarı [Yüksek Lisans Tezi]. İstanbul: İstanbul Üniversitesi Adli Tıp Enstitüsü; 1996.

21. Keskinoğlu P, Giray H, Pıçakçıefe M, Bilgiç N, Uçku R. Yaşlıda fiziksel, finansal örselenme ve ihmal edilme. Türk Geriatri Dergisi. 2004; 7(2): 57-61.

22. İlhan F. Ankara ili yenimahalle ilçesi anadolu mahallesinde aile içi yaşlı istismarının saptanması [Tıpta Uzmanlık Tezi]. Ankara: Gazi Üniversitesi Tıp Fakültesi Halk Sağlığı Anabilim Dalı; 2006.

23. Ergönen AT, Can İÖ, Toprak G. Jinekoloji polikliniğine başvuran kadınlarda yaşı istismarı. Adli Psikiyatri Dergisi. 2007; 4(2): 13-8.

24. Committee opinion no. 568: elder abuse and women's health. Obstet Gynecol. 2013; 122(1): 187-91.

25. Eisikovits Z, Koren C, Band-Winterstein T. The social construction of social problems: the case of elder abuse and neglect. Int Psychogeriatr. 2013; 25(8): 1291-8.

26. Altun ŞÖ. Yaşlı istismarı ve ihmali. II. Uluslararası ve VI. Ulusal Psikiyatri Hemşireliği Kongresi; 4-7 Ekim 2012; Erzurum. 2012. s.27-30.
27. Kingston P, Penhale B. Elder abuse and neglect: issues in the accident and emergency department. Accid Emerg Nurs. 1995; 3(3): 122-8.

28. Koştu N. Yaşlı istismarı ve ihmalinin önlenmesinde halk sağlığ 2(2): 527-34.

29. Akdemir N, Görgülü Ü, Çınar Fİ. Yaşlı istismarı ve ihmali. Sağlık Bilimleri Fakültesi Hemşirelik Dergisi. 2008; 15(1): 68-75.

30. Gülen M, Aktürk A, Acehan S, Seğmen SS, Açıkalın A, Bilen A. Yaşlı İstismarı ve İhmali. Arşiv Kaynak Tarama Dergisi. 2013; 22(3): 393-407.

31. Karadakovan A, editör. Yaşlı sağlığ1 ve bakımı. Ankara:Akademisyen Tıp Kitapevi; 2014.

32. Fadıloğlu Ç, Şenuzun AF. Yaşlıda istismar ve ihmale yaklaşım. Ege Tıp Dergisi. 2012: 51; Ek Sayı: 69-77.

33. Periodic health examination, 1994 update: 4. Secondary prevention of elder abuse and mistreatment. CMAJ. 1994; 151(10): 1413-20.

34. Caregiver abuse screen [Internet]. Canada 2010. [Updated: Feb 2010; Cited: 2015 Oct 12]. Available from: www.nicenet.ca/files/Case.pdf

35. Cohen M. Screening tools for the identification of elder abuse. JCOM. 2011; 18(6): 261-70.

36. Wieland D. Abuse of older persons: an overview. Holist Nurs Pract. 2000; 14(4): 40-50. 